\author{
Mosisili Sebotsa \\ Mosisili Sebotsa is a lecturer in English- \\ French Translation at the National \\ University of Lesotho and a PhD \\ student at the Université Lumière Lyon \\ II, France, focusing on the contribution \\ of translation towards the lexical \\ expansion of Sesotho. \\ Email: mosisili_sebotsa@yahoo.co.uk
}

\section{Translating extra-linguistic culture-bound concepts in Mofolo: a daunting challenge to literary translators}

\title{
Translating extra-linguistic culture-bound concepts in Mofolo: a daunting challenge to literary translators
}

Translating extra-linguistic culture-bound concepts in Mofolo presents a daunting challenge to literary translators as such concepts require that the translator possess a substantial amount of knowledge and background of the Sesotho culture. The present study undertakes a comparative analysis of Thomas Mofolo's Moeti oa Bochabela and its translations Traveller to the East (English) and L'homme qui marchait vers le soleil levant (French) to highlight problems encountered due to lack of understanding of culture-bound extra-linguistic elements (ECE). The article also aims to bring to light translation techniques employed and culture related factors that may hinder the translator from rendering the intended meaning with high accuracy. The semantic analysis of culture-bound extra-linguistic elements shows how readers of the English and French translation may not have a full grasp of the book due to lack of functional equivalence and the disparity in semantic range between Sesotho and the European languages. The impasse of meaning is evidenced throughout the book by the number of words that were either left untranslated or mistranslated as can be observed in the translation of the two poems addressed to Fekisi's cows. The paper uses some of the untranslated and mistranslated elements to show that there is no such a thing as an absolute translation. Keywords: culture-bound extra-linguistic elements, functional equivalence, impasse of meaning, mistranslation, semantic range, translation by omission.

\section{Introduction}

In the process of translating, the main objective is to render information, express clearly defined ideas, and conserve the meaning entailed in the structural systems of the source language, elements without which one would fail to understand either the essence of the text or the inherent concepts. However, in literary translation, another element that the translator cannot ignore is culture, as it forms an integral part of the language. Furthermore, whilst most problems encountered in translation are related to grammar, language structure, terminology, etc., others are culture-bound, which means concepts in the source language (SL) have no functional equivalence in the target language (TL).

In other terms, words encoding cultural information are the most difficult to translate as they require a substantial amount of knowledge and background of the source culture. As expressed by Cordero, "culture-bound concepts, even where the two cultures involved are not too distant, can be more problematic for the translator than the semantic and syntactic difficulties of a text" (qtd. in Leppihalme 2). This 
is due to the fact that culture-bound words and concepts in the SL do not always have a hundred per cent semantic equivalence in the TL and, as such, a pragmatic analytical approach towards understanding culture-bound concepts should not only be based upon linguistic knowledge of the concept under discussion but also on the extra-linguistic information inherent in it as the concept is not studied in isolation but within the framework of a particular language. In other words, language as a culture-bound phenomenon is a reflection of the society owning it and, as a result, any product of cultural translation would be studied in conjunction with the culture from which the source text originates (Bandia 32-7).

Academic work on translation issues abounds, carried out by linguists and translation theorists such as Mounin, Bean, Ladmiral, and others, using literary texts as a battle ground on which they have advanced and defended their ideas. In the final analysis, it becomes evident that the cultural environment (from the source text to the target text) cannot in any way be neglected since the major argument that seems to win the battle is that in transferring the literary message from one language to another, it is in effect cultural aspects that are being transferred from one culture to another. Mounin argues that it is impossible to arrive at a perfect literary translation, especially in poetry. He advances arguments based on history and arguments that are purely based on theory to call into question the quality of translation (style, misleading translation, etc.) of historic works accomplished in a particular historic period.

Ladmiral, on the other hand, claims that Mounin's "prejudicial objection" against translation is totally unreasonable and that there is no need to even doubt whether translation is a possible endeavour. For him proof that it is possible lies in the irrevocable fact that people continue to translate and that sound literary translation works have already been accomplished in many languages. Furthermore, it is impossible to imagine all authors having to learn all the languages in which their work would be published.

This article places itself between Mounin and Ladmiral in that it does not question the possibility of arriving at a sound and acceptable translation, nor does it take for granted that any reputable literary translation is perfect. The study aims to investigate the problems encountered in translating culture specific concepts in the translation of the Sesotho novel titled Moeti oa Bochabela by Thomas Mofolo. Problems encountered in the English version, Traveller to the East, translated by Harry Ashton and the French version, L'homme qui marchait vers le soleil levant (The man who walked towards the rising sun), translated by Victor Ellenberger, are studied as factors that contribute to loss of meaning in translation. The purpose is founded on the hypothesis that the person who reads the English translation or the French version may not have as full a grasp of the book as the person reading the original version in Sesotho because Sesotho culture-bound concepts either do not exist in English and in French or do not have the same semantic range in these two European languages. To accomplish this, the article will identify techniques employed in dealing with culture-bound 
elements and thereafter the frequency of the techniques applied will be studied in detail. ${ }^{1}$ Problems identified in the translations will be studied with the aim to determine the techniques employed and how well they help reconstitute the meaning entailed in the Sesotho cultural concepts.

Wylie states with interest that the dilemmas Mofolo was facing when writing Moeti oa Bochabela were both spiritual and cultural, and whilst Mofolo advocated for change towards Christianity, there is a strong contrast in the novel with regard to the cultural realities that Fekisi, the principal character, has left behind. The two long praise poems addressed to both Tšemeli and Tsoeliea ${ }^{2}$ (Moeti 34-5; Traveller, 42-4; L'homme 94-8) testify to this fact as Mofolo displays the richness of his culture and belonging. In the words of Wylie: "No one has wanted to go so far as claiming Mofolo is presenting an 'ethnographic' portrayal of tradition and oral Sesotho culture with completeness or accuracy, but the impulse in that direction is palpable" (Wylie 165). This article assumes that in this kind of novel, extra-linguistic culture-bound concepts abound to the point that they would present a great challenge to translators.

\section{Semantic implications of extra-linguistic concepts in translation}

Newmark (94) defines culture as "the way of life and its manifestations that are peculiar to a community that uses a particular language as its means of expression". He makes a clear distinction between "cultural", "universal" and "personal" language. Universal words such as sky, cloud, life, animal, etc., would normally not pose a problem in the process of translation. However, extra-linguistic culture-bound words such as pizza, hamburger, sebera (maize that is soaked or cooked and roasted), couscous, etc., would pose a translation problem unless there is an already existing cultural overlap between the SL and the TL including the readership, as in the case of the United Kingdom and the United States, Spain and Portugal and Latin America, the Sotho-speaking part of South Africa and Lesotho, etc. Without a solid cultural background, such terms would be hard to understand, let alone render in a different language.

Translation uses some aspects of applied linguistics. This is supported by Ivir who observes that operationally, translation cannot be fully explained using linguistic science alone, and that the failure of linguistics to develop techniques that respond to problems posed by extra-linguistic elements stems from two causes. Firstly, linguistics is still too young as a discipline to derive solutions that translators in the field can consider as useful. Secondly, by nature, some aspects of translation are not linked to linguistics as they are cultural, social, literary, etc. (615-6). In other words, these are basically the domains in which extra-linguistic culture-bound elements abound, therefore any attempt to translate them literally would be futile as the translation may fail to fully render the meaning entailed due to their varying semantic range in both the SL and the TL. An example would be the words morena and "chief" that 
refer to a universally-known form of leadership but that are understood differently in their separate cultures. Even though "chief" is ordinarily understood to be the equivalent of morena, originally the two were not equivalents. Casalis, Machobane, and Rosenberg and Weisefelder attest that at the beginning of the nineteenth century, the politico-administrative structure of Lesotho was centred on Morena, translated as "Chief' by some missionaries whilst its sociolinguistic or cultural meaning was closer to "protector" or "he who watches over the public safety and welfare". Semantically speaking, at the beginning of the nineteenth century, morena could not be functionally equated to "chief" as the two terms did not have the same semantic range in their separate cultures. However, it would be hard not to assume that these days these terms are viewed by Basotho translators as equivalents.

There exist academic works in relation to the translation of extra-linguistic culturebound concepts by scholars such as Ivir, Leppihalme, Negro Alousque, Elyildirim, and others. However, the proposed model is a combination of adapted models suggested by Pedersen and Newmark, and is based on the data collected from the translations of the English version Traveller to the East and the French version L'homme qui marchait vers le soleil levant in comparison with the original Moeti oa Bochabela. Considering that the corpus is too expansive to be analysed in its entirety, the article will focus on elements bearing what Pedersen calls an extra-linguistic culture-bound reference which is defined as follows: "Extra-linguistic culture-bound reference (ECR) is defined as reference that is attempted by means of any culture-bound linguistic expression, which refers to an extra-linguistic entity or process, and which is assumed to have a discourse referent that is identifiable to a relevant audience as this referent is within the encyclopaedic knowledge of this audience". Pedersen expresses ECRs, in other words, as terms and expressions relating to realia, to cultural elements which are not part of TL systems. As such, the model does not include a holistic analysis of intra-linguistic culture-bound references such as poetry, idioms and proverbs, even though they are opaque enough to be considered as factors that contribute to loss of meaning in the translation of Moeti oa Bochabela. However, extra-linguistic culture-bound concepts appearing in the novel will be studied in relation to their contribution to loss of meaning in the translation in both English and French. In the present study, I shall employ the expression extra-linguistic culture-bound element (ECE) instead of ECR.

Extra-linguistic elements are identified and extracted from the original in Sesotho and then traced in the English and the French translations in order to carry out a comparative semantic analysis to determine whether or not meaning has been lost in translation. To this end, extra-linguistic elements are categorised based on the techniques employed to reconstitute the meaning in the TL.

Pedersen identifies two technical categories under which translation of extralinguistic culture-bound elements can be classified, the SL oriented category and the 
TL oriented category. Under each category, there are techniques that are employed to render ECEs. The SL oriented category consists of three techniques, namely retention, specification and direct translation, each of which has sub-techniques. The TL oriented category consists of three techniques, namely substitution, generalisation and omission, each of which has sub-techniques. Translation methods such as wordfor-word translation, faithful translation, semantic translation, and so on elaborated by Newmark (45-7) will be integrated into the analysis to determine the fidelity of the English and French translations to the original in Sesotho. Only relevant techniques will be used for analysis.

Retention is the commonly used source oriented technique that allows ECEs from the SL to enter and sometimes integrate into the TL. In some cases, retained ECEs are distinguished from the vernacular language or TL by use of quotation marks or italics or by slightly adjusting their original structure. In a way, retention would be the technique that appears to be the most faithful to the SL as the translator is not only true to the text but also to the very letter of the SL.

Specification refers to leaving the ECE untranslated but providing information that does not appear in the original source text (ST), thus rendering the target text (TT) more specific than the ST. To this end, translators employ one of the two sub-techniques, namely explicitation or addition. In the present model, explicitation is understood to refer to expansion of the text or clarification of anything implicit in the ST. It also refers to hidden information in the ST ECE that readers in the source culture are familiar with. Such information may need to be disambiguated in the target culture (for example, writing acronyms or abbreviations in full and writing official names in full). Addition is carried out by translator to give guidance to the target culture (TC) because information in the ECE is hidden and therefore has some connotations.

In direct translation, the translator makes no effort to bring about any semantic modifications with the aim to transfer connotations of the TC. The technique has two sub-techniques namely calque and shifted techniques. Generally, calque is a form of literal translation that sometimes appears exotic.

Semantic analysis of extra-linguistic culture-bound elements in Moeti oa Bochabela Sesotho extra-linguistic culture-bound elements are innumerable in the novel Moeti oa Bochabela. However, for a Sothophone who is conversant in both English and French, the title in Sesotho encodes latent cultural information. ${ }^{3}$ Bochabela relates to the cultural origin of Basotho, Ntsoana-Tsatsi, what Wylie refers to as "the mythical east", but what in reality represents a concept engraved in the cultural memory of every Mosotho child through oral and written culture. In other words, without delving into archaeological scientific facts, in the oral tradition of Basotho, Ntsoana-Tsatsi relates to the origin of Basotho as part of the Bantu expansion or Bantu migration as alluded to by Mofolo (15) himself in Moeti oa Bochabela: "Na ekaba o ahile Ntsoana-Tsatsi, 
moo batho ba reng ba tsoa teng?" "Could it be that he abides in Ntsoana-Tsatsi, where people claim to originate?").

Semantically, even before attempting to read the book, the title in English, Traveller to the East, carries no such cultural connotation, whilst the French translation, L'homme qui marchait vers le soleil levant, makes a half attempt by opting for semantic translation that veers more towards appropriation. In the end, it remains beautiful but fails to communicate the cultural aspects latent in Mofolo's title.

Whilst cases of retention abound in the novel, the article uses those that clearly have no functional equivalence in the $\mathrm{TL}$, and which have forced the translator into the impasse of having to retain the terms encoding the extra-linguistic cultural information as can be observed in Table 1 below:

\begin{tabular}{|l|l|l|}
\hline Lesiba & $\begin{array}{l}\text { He had not played his lesiba instrument when the cattle went } \\
\text { out as it was still early. }\end{array}$ & Page 12 \\
\hline Nts'oana tsatsi & $\begin{array}{l}\text { He asked himself where that God spoken of by his elders } \\
\text { lived. If perchance a person to him, can he hear? Does he } \\
\text { perhaps live at Ntsoaa tsatsi where people say they came from? }\end{array}$ & Page 18 \\
\hline Kholumolumo & $\begin{array}{l}\text { They told him the things of long ago, of old time, which they } \\
\text { had heard told them. They told him about Kholumolumo. }\end{array}$ & Page 21 \\
\hline Sankatana & $\begin{array}{l}\text { The men told Fekisi the tale of the boy Sankatana. They told } \\
\text { him also that there a God, although He is far away from } \\
\text { people, on account of their disobedience. }\end{array}$ & Page 23 \\
\hline Tšemeli & $\begin{array}{l}\text { White faced Tšemeli, finest of the herd, } \\
\text { In the greenness of spring it throws off the herd boys, } \\
\text { the oxen are casting the long hair of winter. }\end{array}$ & Page 42 \\
\hline
\end{tabular}

Table 1: Retention as a translation technique in Traveller to the East

And in the French translation:

\begin{tabular}{|l|l|l|}
\hline Lesiba & $\begin{array}{l}\text { Lorsqu'il emmenait le troupeau de très grand matin de la sorte, } \\
\text { il ne jouait pas son lesiba. }\end{array}$ & Page 54 \\
\hline Nts'oana tsatsi & $\begin{array}{l}\text { Où donc, se demandait-il, habite ce Dieu dont les vieux nous } \\
\text { parlent ? Peut-il entendre les hommes lui parlent ? Serait-ce } \\
\text { à Ntsoaa tsatsi qu'il demeure, Ntsoana tsatsi où les hommes ici } \\
\text { disent que c'est le berceau de leur race? }\end{array}$ & Page 61 \\
\hline Kholumolumo & $\begin{array}{l}\text { Ils lui parlèrent des temps de jadis, des tout premiers temps } \\
\text { de l'histoire, comme on leur en avait rapporté la tradition. Ils } \\
\text { lui racontèrent l'histoire de Kholumolumo. }\end{array}$ & Page 65 \\
\hline
\end{tabular}




\begin{tabular}{|l|l|l|}
\hline Sankatana & $\begin{array}{l}\text { Ce conte et sa conclusion, mes lecteurs la connaissent, aussi } \\
\text { je ne m'étendrai pas davantage sur ce sujet. Ceux qui racon- } \\
\text { taient cette histoire à Fekisi soulignent ce haut fait du fils de } \\
\text { Sankatana. }\end{array}$ & Page 67 \\
\hline Mokhibo & $\begin{array}{l}\text { Quand les jeunes filles s'amusaient ou dansait, ou bien } \\
\text { jouaient à genoux au mokhibo, ou encore chantaient, leurs yeux } \\
\text { se tournaient tous vers lui, cherchant chacune d'entre elles à } \\
\text { attirer son attention, chacune savait dans son intérieure que si } \\
\text { elle chantait, c'était pour lui, bien qu'elle ne le laissât pas voir. }\end{array}$ & Page 107 \\
\hline Tšemeli & $\begin{array}{l}\text { Ô Tšemeli, face blanch, la plus belle, } \\
\text { la plus belle et forte du troupeau, } \\
\text { Qui te joues des bergers dans le vert printanier... }\end{array}$ & Page 94 \\
\hline Tsoelia & $\begin{array}{l}\text { Ô toi bête des bergers à la corne plus haute que l'autre, } \\
\text { La-Noire, Tsoelia, appartenant au chef des jeunes gens... }\end{array}$ & Page 96 \\
\hline
\end{tabular}

Table 2: Retention as a translation technique in L'homme qui marchait vers le soleil levant

In both English and French, it is evident that lesiba, ntsoana tsatsi, kholumolumo and sankatana do not have a functional equivalence. As per Newmark (45-7), in both languages, Ashton and Ellenberger employed retention as a word-for-word technique and specification to attempt free translation as can be observed in context with lesiba and ntsoana tsatsi. Although Ashton does not write extra-linguistic culturebound terms in italics nor does he put them in quotes, he specifies that lesiba is an instrument, admittedly latent information in the original but a necessary addition in English since lesiba may also refer to a feather. He also makes lengthy footnotes and translator's notes to clarify that ntsoana tsatsi means "the rising sun". The same thing is observed in French where Ellenberger writes lesiba in italics and goes a step further by making explicit how the instrument is manufactured as well as explaining how it is played. It should be noted at this stage that this technique as employed by Ashton and Ellenberger is a good attempt to put lesiba in a proper context. However, despite the effort to specify and explicit the ECE, without a solid Sesotho cultural background, it remains impossible to render these concepts holistically. Without the visual artefact and a lived cultural experience, the concept being described remains incomplete, which means some meaning is lost in translation as the reader may fail to associate lesiba with cows. Lesiba is a common instrument in pastoral communities of Lesotho where livelihood is based on raising livestock. It is the main form of entertainment for shepherds while tending livestock.

The same thing can be observed with regard to kholumolumo, moshanyan'a sankatana and mokhibo. Mofolo feels no need to explain them in Moeti oa Bochabela. Although he is referring to a fictitious monster and a fictitious character in the tales of Baso- 
tho, they remain cultural concepts whose significance goes beyond linguistic rules governing the Sesotho language. As a result, translating them would require more than just language, especially when there is neither cultural overlap nor readership between Sesotho and French, and when the existing readership between Sesotho and English is overly imbalanced in favour of English. Mokhibo, written in italics in the French version, is a clear case of retention as no such dance exists in France and therefore it would be hard to even explicate it. This means a French person, born and raised in France, would miss certain information as the meaning inherent in the cultural imagery of the mokhibo is not captured in the translation.

Proof that translation of extra-linguistic culture-bound concepts in Moeti oa Bochabela did present a daunting challenge lies in the explicitation of Tšemeli. While Ashton retains the word without any explanation, Ellenberger retains it and commits an error of mistranslation. Whether Ashton was aware that in Sesotho cows are normally given names is unknown, however it is evident that Ellenberger understood Tšemeli to refer to a bird as can be observed in the footnote where he provides the bird's scientific name Lanius collaris in italics as well as the common name pie-grièche in French. This footnote may be totally misleading as it does not explicit that in this case Tšemeli should be understood as the name of Fekisi's white-faced cow. In other words, the same state of impasse of meaning in which the translator found himself is inadvertently transferred from the translator to the reader as the latter may be lost in the process of trying to find the relationship between the cow and the bird. In the same context, an inconsistency with regard to the translation of the grey cow named Tsoelia is observed. Ellenberger retains the word without any footnote, while Ashton opts for translation by omission. While the English reader may not even be aware of the omission, the French reader, not knowing that, in the Sesotho culture, cows are normally given names, may find himself/herself at an impasse of meaning, wonder what the word Tsoelia refers to since an explanatory footnote was provided for the white-faced cow. If Tšemeli is Lanius collaris or pie-grièche, then what would the scientific name for Tsoelia be or what would it refer to? This question would not only be logical but also legitimate considering that Tšemeli and Tsoelia are used in the same context-of poetry and with reference to cows. If, in the French version, there is a footnote, in relation to the white-faced cow, attempting to explain what Tšemeli means, why is there no footnote or translator's note in relation to the grey cow, trying to explain what Tsoelia is? In this case, the focus would be on the technique of consistency, as far as professional translation is concerned.

This dilemma in which both Ashton and Ellenberger found themselves, as literary translators, is well explained by Bandia (40): "The translation of names, particularly in contexts where they carry great significance, is quite often a daunting task since names are usually culture specific and circumscribed within specific cultural para- 
digms. Owing to the culture-specificity of African names, reference and modes of address, they do not often have direct equivalents in European languages".

There is a thin line between the techniques of direct translation, specification and omission in the translation of Moeti oa Bochabela. While direct translation does not contribute to loss of meaning in translation, it is studied here as an introduction to the technique of specification, leading to translation by omission.

The present study only takes interest in extra-linguistic borrowing following the observation made by Hatim and Maison (223-4) that, in some literary works, the translator is considered more of a cultural intermediary than a mere linguistic intermediary in which case the translator may be confronted with a hard choice of borrowing especially when there are no functional equivalents in the TL. Chartier defines extra-linguistic borrowing as a stylistic process used in relation to specific cultural phenomena. It is generally employed when the translator or the author wants to relate to a period or a historic event or even give the text a remarkable aspect of exoticism if not a local flavour (63-9). This can be observed in Traveller to the East and L'homme qui marchait vers le soleil levant where Ashton and Ellenberger could have simply opted for evening star (English) or étoile du berger (French) in place of sefala bohoho (Sesotho). In the same manner, they could have opted for the Milky way (English) or la voie lactée (French) in place of molala (Sesotho) as, in this case, the semantic range between Sesotho and the two European languages is one hundred per cent and therefore these qualify as functional equivalences. However, Ashton (23) went further by explaining the cultural significance of sefala bohoho (overlooked by Ellenberger) which he explicates in the footnote: "The evening star, literally the crust-scraper. Its appearance tells the women it is time to scrape out the pots for the evening meal".

On the other hand, khotla is not an extra-linguistic borrowing, rather a culturebound concept that is probably one of the most difficult Sesotho extra-linguistic concepts to translate as it is at the heart of the Basotho cultural institution. Ellenberger places the term in italics on page 95 and makes a brief translator's note, "council court for men".

Machobane (14) defines khotla as follows: "The court-where public affairs were discussed and settled, disputes were resolved, and when there no were problems, men's public works-softening cowhides for blankets and dresses, sandal-making and so on-were undertaken". With Machobane's definition in mind, it becomes clear that there is a double complication, that of the term designating an extra-linguistic culture-bound concept that does not exist either in English or in French, and that of the term appearing within the context of a praise poem. The latter makes it almost impossible to comprehensively render the concept in a manner that a European reader would have a full grasp of the meaning of the text as a Mosotho. As Masseau (203) puts it: "The translator who attempts to recreate a poem that is semantically 
and rhythmically equivalent to the original should not only concentrate on the unit at hand, but rather analyse the text in its entirety and identify the relationships that exist between different elements of the text" (my translation).

Considering Masseau's opinion, the question, in the case of Moeti oa Bochabela, remains, would recreating Mofolo's two-page poem assist in rendering culture-specific elements such as khotla and 'mampoli? In contrast, Ashton, for his part, preferred translation by omission. This avoids literal translation or leaving the words khotla and 'mampoli untranslated and putting them in inverted commas as in the case of Ellenberger. In this regard, translation by omission qualifies as a fairly good attempt at a faithful translation that reproduces the contextual meaning of the original but fails to render culture-bound concepts. My position in this regard is that Ashton's omission of these Sesotho extra-linguistic culture-bound concepts khotla and 'mampoli contributes to loss of meaning in translation. Taking 'mampoli for example, he simply translates it as: "All the rights belonged to the strong man, he did as he wished" (Ashton 2). A Sothophone who is conversant in English makes a clear difference between a "strong man" and "mampoli. Reading Traveller to the East one would fail to understand that the author is referring to "mampoli and not the strong man per se since culturally, the distinction between "mampoli and a "strong man" is clear. Thus 'mampoli is a concept whose definition veers more to the sense of a particular strongest man who exercises control and authority over others on a quasi-permanent basis whilst the notion of a "strong man" has the connotation of any strong man of the day. ${ }^{4}$ In this context, it would refer to the chief shepherd.

On the basis of the arguments provided, it becomes manifest that any translation that is otherwise deemed as satisfactory by non-speakers of the source language, when analysed from the cultural perspective of source language by a specialist, can still appear as average and needing improvement, in as far as culture-bound extralinguistic concepts are concerned. This is due to the fact that the specialist looks in vain for the symmetric understanding of the text in the target language, wanting to produce the replica of the source text, only in another language. However, this remains a challenge.

\section{Conclusion}

From the translator's point of view, it becomes clear that linguistic knowledge alone is not enough to understand a literary text in Sesotho, the language from which Traveller to the East and L'homme qui marchait vers le soleil levant were translated, as the meaning inherent in the Sesotho culture-bound extra-linguistic elements is almost impossible to transfer holistically or with high accuracy in English and French. It also becomes clear that intercultural communication, particularly between distant languages such as European languages and African languages requires the reader to make a conceptual shift in the cultural context in which the extra-linguistic concepts 
would actually make sense. Any impasse of meaning on the part of the translator is generally transferred to the target text either by mistranslation or by omission, factors that generally contribute to loss of meaning in translation. In a broader perspective, it becomes clear that there is no such a thing as an absolute translation, that every translation can be criticised and that, sometimes, a translation is deemed as good or bad based on the reader's perspective and preference depending on the comprehensibility of the translation and how well the reader relates to the translation.

Notes

1. Pedersen, in his article "How is Culture Rendered in Subtitles?" prefers the term "strategies" instead of the term that is generally used in technical translation, "techniques".

2. As mentioned in the poem, Tšemeli is the name of the white faced cow while the gray cow's name is Tsoeliea.

3. The term Sothophone is used deliberately here to establish the difference between a person who is born and raised in the Sesotho culture and one who may have learnt how to speak Sesotho without possessing any cultural knowledge of culture-bound extra-linguistic concepts in Sesotho.

4. The cultural understanding of the concept of ' mampoli is also encompassed by the definition provided in the Sesuto-English Dictionary (Mabille 229): "the eldest or strongest or the most important of a troop of boys".

\section{Works Cited}

Bandia, F. Paul. Translation as Reparation. Manchester: St. Jerome Publishing, 2008.

Casalis, Eugène. The Basutos, or Twenty Three Years in South Africa. London: James Nisbet \& Co., 1861.

Chartier, Delphine. La Traduction Journalistique Anglais-Français. Toulouse: Presse Universitaire du Mirail, 2000.

Ellenberger, D. F. History of the Basuto: Ancient and Modern. Morija: Morija Museum and Archives, 1992.

Elyildirim, Selma. "The Importance of Cultural Knowledge in Translation: A Partial Replication of Olk." Journal of Social Sciences 17 (2008): 131-44.

Hatim, Basil \& Ian Mason. Discourse and the Translator. London: Longman, 1990.

Holmes, James, et al. The Nature of Translation: Essays on the Theory and Practice of Literary Translation. The Hague: Mouton \& Co., 1970.

Ivir, Vladimir. "Linguistic and Extra-linguistic Considerations in Translation." Studa Romanic et Anglica Zagrabiensa 33-36 (1972): 615-26.

Ladmiral, Jean-René. Traduire: Théorèmes pour la Traduction. Paris: Edition Gallimard, 1994.

Leppihalme, Ritva. Culture Bumps: An Empirical Approach to the Translation of Allusions. Clevendon: Multilingual Matters, 1997.

Mabille, A. Sesuto-English Dictionary. Morija: Morija Printing Works, 2000.

Machobane, L. B. B. J. Government and Change in Lesotho 1800-1966. London: Macmillan, 1990.

Masseau, Paola. Une Traductologie de la Poésie est-elle Possible? Paris: Éditions Publibook, 2012.

Mofolo, Thomas. Moeti oa Bochabela. Morija: Morija Sesuto Book Depot, 1907. 2003.

. Traveller to the East. Trans. H. Ashton. Johannesburg: Penguin Books, 2007 [1933].

Mounin, George. Belles Infidelles. Paris: Cahiers du Sud, 1955.

Negro Alouesque, Isabel Negro. "Cultural Domains: Translation Problems”. Revista de Lingüística y Lenguas Aplicadas 4 (2010): 137-45.

Newmark, Peter. A Textbook of Translation. Hertfordshire: Prentice Hall, 1988.

Pedersen, Jan. "How is Culture Rendered in Subtitles?" 24 Feb. 2015. < http://www.euroconferences.info/ proceedings/2005_Proceedings/2005_Pedersen_Jan.pdf $>$.

Reiss, Katharina. "Type, Kind and Individuality of Text: Decision Making in Translation." The Translation Studies Reader. Ed. Lawrence Venuti. London: Routledge. 160-72, 2000. 
Rosenberg, Scott and Richard F. Weisefelder. Historical Dictionary of Lesotho. Lanham, MD: Scarecrow Press, 2005.

Samakar, Saeed. "Translation of Extralinguistic Culture-Bound Elements in Persian Movies

Subtitles into English: A Case Study of The Lizard". 6 Dec. 2015. <http://www.translationdirectory.com/ articles/article2110.php>.

Wylie, D. "Reviewed Work: Traveller to the East by Thomas Mofolo, Harry Ashton, Stephen Gray." English in Africa 35.2 (2008): 163-6. 